\title{
HABITAT USE BY BIRDS IN AIRPORTS: A CASE STUDY AND ITS IMPLICATIONS FOR BIRD MANAGEMENT IN SOUTH AMERICAN AIRPORTS
}

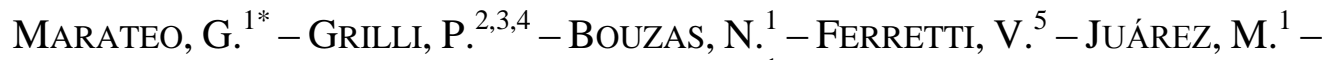 \\ SOAVE, G.E. ${ }^{1}$ \\ ${ }^{I}$ Facultad de Ciencias Naturales y Museo, \\ Universidad Nacional de La Plata, Argentinal22 y $60 \mathrm{~s} / \mathrm{n}$ \\ (phone: +54-221-4833-198) \\ ${ }^{2}$ Dirección de Áreas Naturales Protegidas de la Provincia de Buenos Aires, \\ Organismo Provincial para el Desarrollo Sostenible (OPDS). \\ Avda. 532 y $13,2^{\circ}$ piso, La Plata, Argentina \\ .$^{3}$ Cátedra de Ecología General y Recursos Naturales, \\ Universidad Nacional Arturo Jauretche, Avda. Calchaqui 6200, Florencio Varela, \\ Argentina. \\ ${ }^{4}$ Cátedra de Ornitología, Facultad de Ciencias Naturales y Museo, \\ Universidad Nacional de La Plata, Argentina 122 y $60 \mathrm{~s} / \mathrm{n}$ \\ ${ }^{5}$ Neoambiental (Environmental consultant), Avda. Arana 949, \\ Villa Elisa, La Plata, Argentina \\ (phone: +54-221-4871-839) \\ *Corresponding author \\ e-mail: gmarateo@yahoo.com \\ (Received $14^{\text {th }}$ Dec 2012; accepted $2^{\text {nd }}$ Aug 2014)
}

\begin{abstract}
The concentration of birds around airports has significantly increased the occurrence of aeronautical accidents worldwide. One of the main techniques to modify the avian habitat in airports, and therefore exert controls over bird population density, is to regulate the height of surrounding grasslands. The objective of this work was to record the seasonal use of habitat by birds in an airfield in Argentina, and to evaluate the effect of grassland height in the abundance of different components of the avian community. A total of 44 sampling events were carried out between October 2005 and July 2011, comprising all seasons. Short grassland areas $(\leq 30 \mathrm{~cm})$, registered $53 \%$ of the total bird abundance, and were consistently for all seasons the most utilized habitat by those species that registered the highest abundances (e.g. Milvago chimango and Vanellus chilensis) and that pose a highest risk to aerial operations. In general, the species Patagioenas picazuro, Zenaida auriculata, Myiopsitta monachus and Sturnus vulgaris also made preferential use of short grassland areas rather than tall grasslands. Maintaining grassland areas at heights $>30 \mathrm{~cm}$, might be a successful habitat manipulation strategy and represent a tool to control birds in South American airports. In turn, this would be a relatively simple and economic management strategy.
\end{abstract}

Keywords: bird strikes, wildlife hazard, human-wildlife conflicts, grass management, habitat management

\section{Introduction}

Since the beginnings of aviation the occurrence of birds in and around airports and airfields has contributed to an increase in aeronautic accidents worldwide (Sodhi, 2002). Airports are attractive areas for some bird species because they are built around open spaces 
with grasslands and tree groves of various heights, and are adjacent to areas of high urban density, providing resources such as food, shelter, and resting and nesting grounds (Froneman, 2000; Sodhi, 2002; Transport Canada, 2002; Cleary and Dolbeer, 2005).

In military aviation about $54 \%$ of aircraft collisions with birds take place on the airstrip or its surroundings, and this figure goes up to $95 \%$ in civil aviation (Burger, 1983; Smith, 1986; Neubauer, 1990; Cleary et al., 1999; ICAO, 2009; ATSB, 2010; Galvão Novaes and Del Valle Alvarez, 2010). In order to reduce the occurrence of accidents, the International Civil Aviation Organization has exhorted all its affiliate countries to evaluate bird-related risks in airports, and to develop appropriate management and control programs (ICAO, 2001).

Among the variety of bird control methods in airports (Hygnstrom et al., 1994; Transport Canada, 2002; Cleary and Dolbeer, 2005), avian habitat management seems to be the most effective in the long run. However, habitat management does not necessarily guarantee complete control over birds, and it is generally required that this strategy is combined with active controls (Barras and Seamans, 2002; Sodhi, 2002; Transport Canada, 2002; Cleary and Dolbeer, 2005). Adequately managing grassland height by keeping it below $30 \mathrm{~cm}$, constitutes one of the main habitat management techniques in airports, reducing bird abundances and therefore the chance of accidents (Mead and Carter, 1973; Brough and Bridgman, 1980; Dekker and van der Zee, 1996; Deacon and Rochard, 2000; Civil Aviation Authority, 2002; ATSB 2010).

However, the management of grassland height has somehow yielded opposing results; while it was effective in the UK (Deacon and Rochard, 2000), in the USA it has produced contradictory or ambiguous results, probably due to the different bird and grass species at play (Seamans et al., 1999; Barras and Seamans, 2002; Sodhi, 2002; Washburn and Seamans, 2004; Seamans et al., 2007; Carragher et al., 2012). Studies on habitat use by birds in South American airports are fairly recent and few, and the grassland management recommendations that arose from them are very broad, shortterm, and not do not incorporate seasonality and inter-annual variations (e.g. Guedes et al., 2010; Marateo et al., 2011).

The relationships between avifauna and vegetation in South American airports, might differ from the patterns described for other parts of the world, given that the ecological communities are not the same. Therefore, it is of utmost importance to carry out midand long-term studies, in order to provide effective management strategies for this region. The aim of this study was to record seasonal habitat use patterns by bird species that pose a higher risk for aircraft, in an airfield in Argentina, and to evaluate the effect of grassland height on their abundances.

\section{Materials ant methods}

\section{Study area}

This study was carried out at Campo de Mayo airfield $(\mathrm{CMA})($ surface area $=130$ ha), located in NE Buenos Aires Province, Argentina (34 32' 04.80' S - 58 40' 17.63 " W) (Fig. 1). The area is a mosaic of open and forested areas, and densely-populated urban centers. The airfield has a 1,800 m-long paved runway, and is surrounded by grassland patches and tree groves, taxiways, heliports, areas of pavement, hangars and other buildings.

Since 2005, an uninterrupted bird control program has been implemented at CMA, mainly aimed at controlling Chimango Caracaras (Milvago chimango). As a result of 
the first field studies, two groups of this species were identified in relation to their use of space, residence time and degree of aggregation (Marateo et al., 2012). Accordingly, the two groups were: visiting Chimango Caracaras (with maximum abundances $>6,000$ individuals), which are controlled by pyrotechnics (Marateo et al., 2012); and resident Chimango Caracaras, which are controlled by a combination of measures including pyrotechnics, elimination of shrubs and nest removal.

A total of four accidents involving birds have been reported for the airfield since 2005, namely: two involving Chimango Caracaras, one involving the Southern Lapwing (Vanellus chilensis), and one involving the Campo Flicker (Colaptes campestris). However, there are a number of unreported incidents with airplanes and helicopters, which involved mainly the first two species mentioned (CMA authorities, pers.com.).

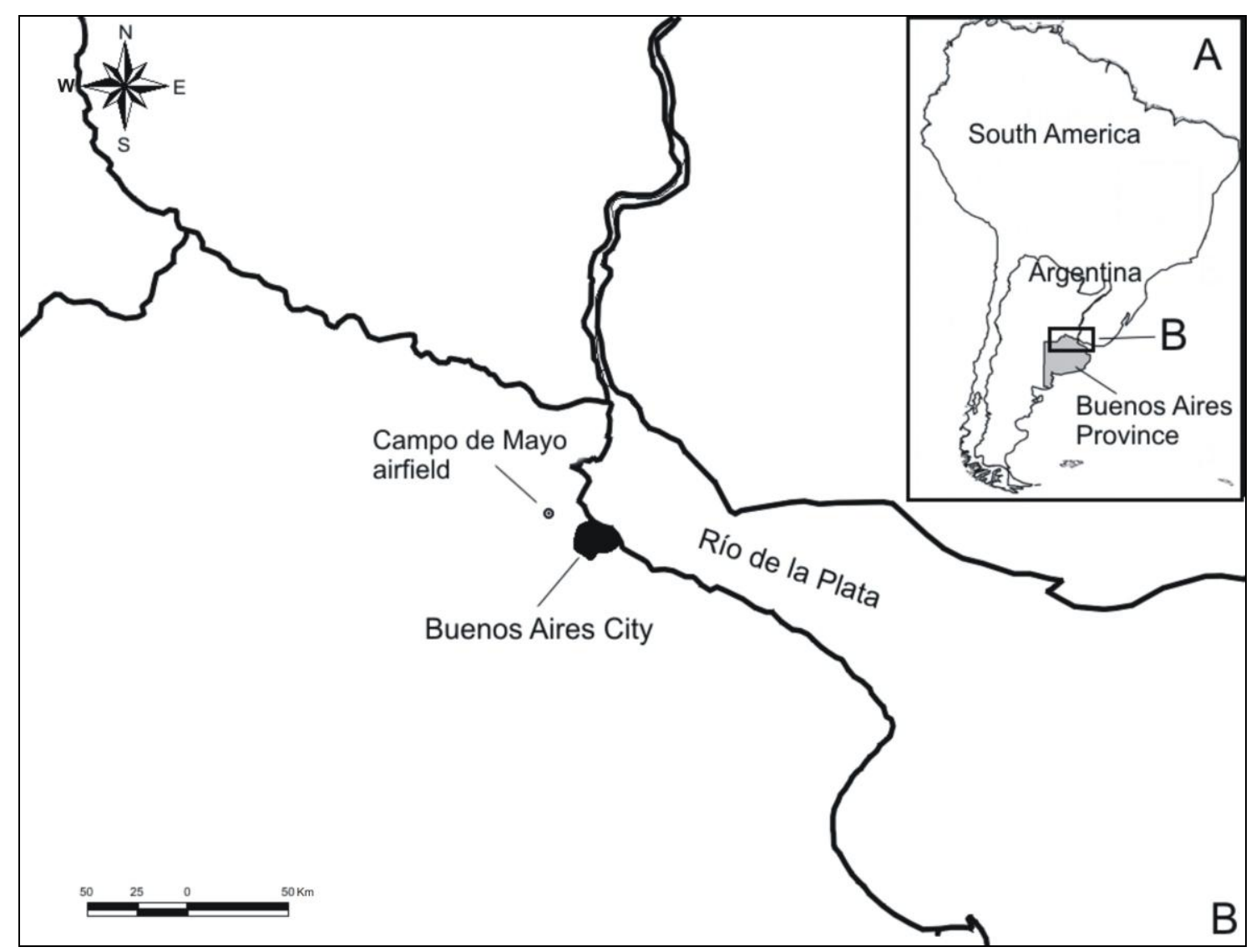

Figure 1. Study area. Campo de Mayo airfield located in NE Buenos Aires Province, Argentina $\left(34^{\circ} 32^{\prime} 04.80^{\prime \prime} S-58^{\circ} 40^{\prime} 17.63^{\prime \prime} \mathrm{W}\right)$.

\section{Sampling}

A total of 44 bird sampling events were carried out between October 2005 and July 2011 at CMA, comprising all seasons. Three observers were placed at different sectors of the airfield in order to sample these simultaneously by covering the total area with trajectories lasting $\sim 30 \mathrm{~min}$. Observers rotated between sectors in order to even out possible differences in data recording between them. Sampling took place at different times throughout the day in order to minimize possible differences in the daily activity of birds. 
In each sampling event the total number of (observed and heard) birds were counted at different sectors of the airfield, recording the species, number of individuals and their use of habitat. Avian habitats were classified as:

1. Short grassland: areas with a dominance of herbaceous species and grasses < $30 \mathrm{~cm}$ in height,

2. Tall grassland: areas with a dominance of herbaceous species and grasses $>30$ $\mathrm{cm}$ in height,

3. Trees: wooded patches of varying extent or isolated trees,

4. Runway,

5. Taxiways,

6. Buildings.

Finally, the category "in flight" was considered in those cases in which individuals only used the aerial space as a transit zone and did not make use of any other habitats during sampling.

The extent of the tall- and short grassland areas varied throughout the study, hence two grassland heights were considered $(\leq 30 \mathrm{~cm}$, and $\geq 30 \mathrm{~cm})$, independently of their location within the airfield and the surface area covered by either one. Landscape management of grassland areas was not performed consistently at CMA, and therefore we assumed no significant effect of the cover area and location of the tall- and short grasslands.

\section{Data analysis}

Differences in species abundance between habitats were analyzed for each season by means of Friedman's non-parametric two-way ANOVA, or repeated measure ANOVA. A posteriori multiple comparisons were based on the mean values for each treatment rank, and the variances of the ranks (Conover, 1999).

\section{Results}

Averaged total abundance was 236 birds $(\mathrm{SD}= \pm 117 ; \max =645 ; \min =48 ; \mathrm{N}=44)$. The most abundant species were the Chimango Caracara (36\% total abundance); the Southern Lapwing (34\% total abundance); the Picazuro Pigeon (Patagioenas picazuro) and the Eared Dove (Zenaida auriculata; $11 \%$ total abundance); the Monk Parakeet (Myiopsitta monachus; $9 \%$ total abundance); and the Common Starling (Sturnus vulgaris; $6 \%$ total abundance). Short grassland areas registered $53 \%$ of total bird abundance, followed by the runway with $14 \%$, the aerial space with $13 \%$, tree groves with $8 \%$, tall grassland areas with $5 \%$, and taxiways and buildings with $3 \%$ in each.

Significant differences were recorded between habitats in the abundances of Chimango Caracaras, Southern Lapwing and pigeons and doves, for all seasons. Chimango Caracaras and Southern Lapwing were consistently more abundant in short grassland areas. Pigeons and doves made a more extensive use of the aerial space of CMA, and were also more abundant in short- than in long grassland areas, during fall, winter and spring. Monk Parakeet showed significant differences in their abundances between habitats only in winter, and were generally more abundant in short grassland areas (Table 1, Fig. 2). 
There were no significant differences between habitats in the abundance of the Common Starling, although they were more abundant in the short grassland in winter and spring (Table 1, Fig. 2).

$$
\text { Spring Summer } \quad \text { Fall Winter }
$$

Chimango Caracara

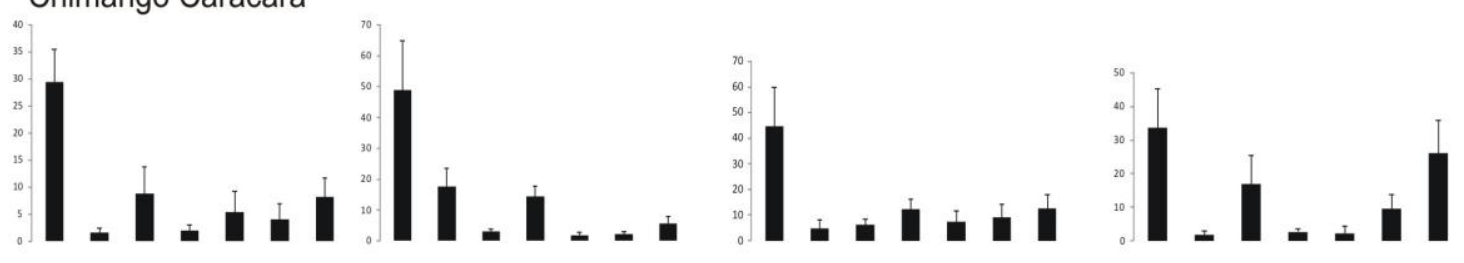

Southern Lapwing

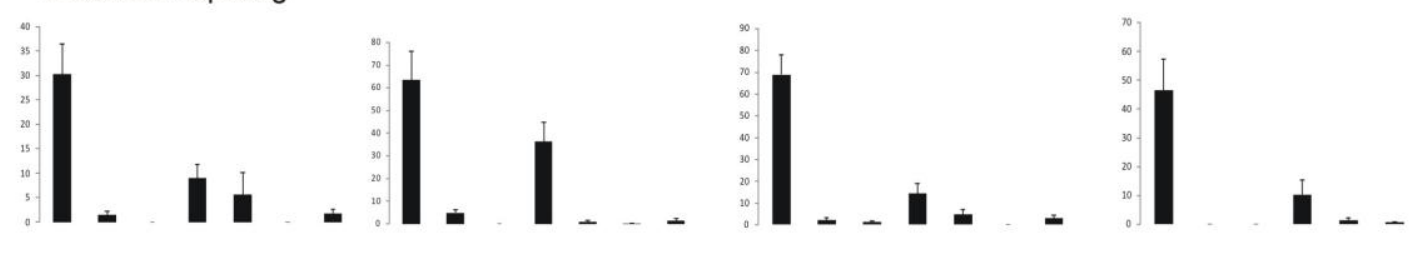

Pigeons and Doves

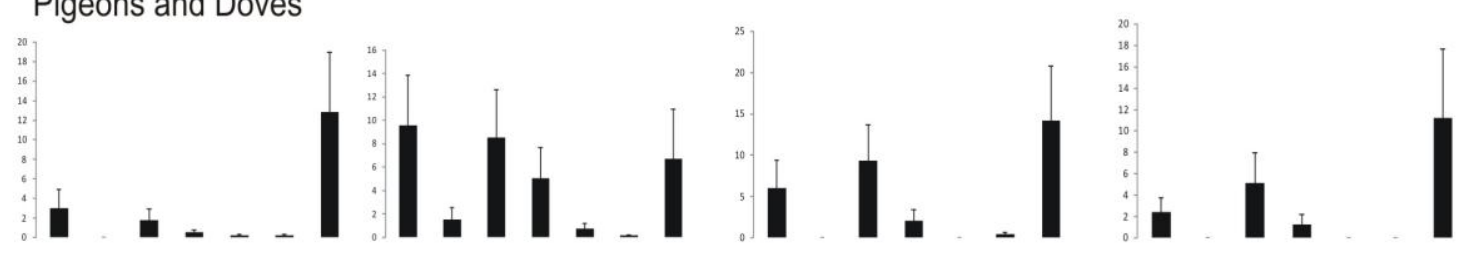

Monk Parakeet
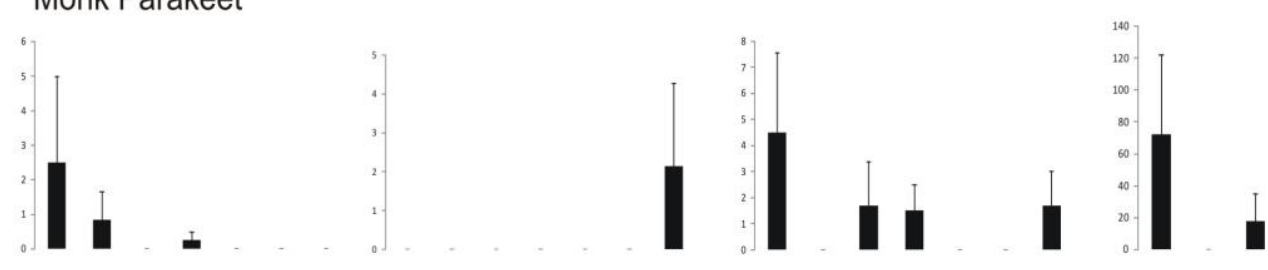

Common Starling

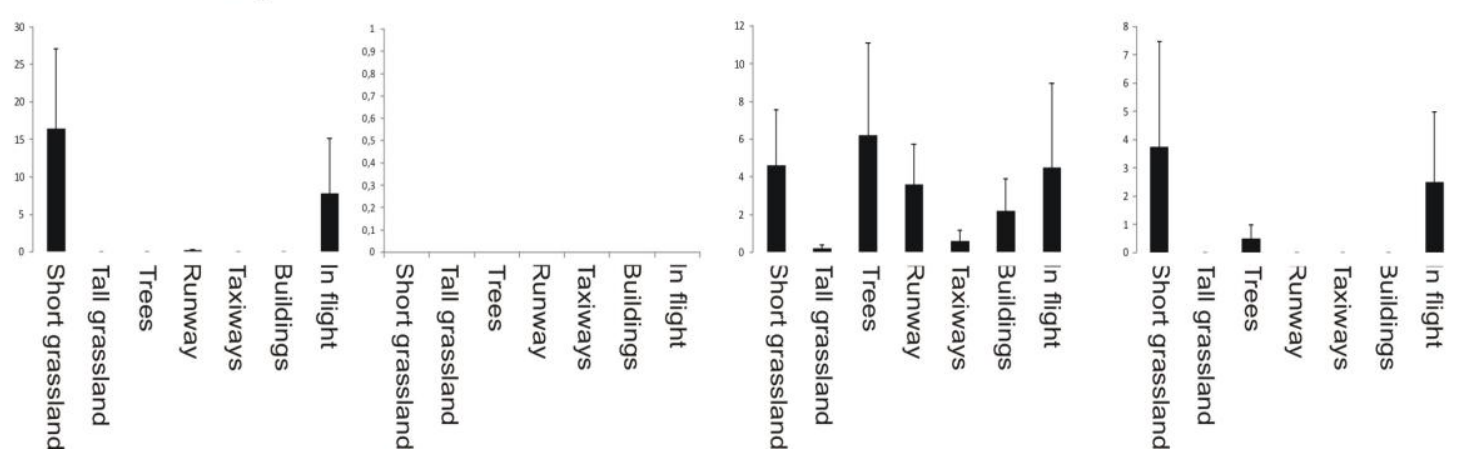

Figure 2. Bird species abundance by habitat and season for CMA for six consecutive year. 
Even when the use of trees was not important on average, higher abundances in this habitat were recorded for pigeons and doves in most seasons, for the Monk Parakeet in fall and winter, and for the Common Starling in the fall. Relatively important abundances of the Southern Lapwing were recorded in the runway, mainly during summer (Fig. 2).

Table 1. Results from Friedman's ANOVAs, and a posteriori tests on the number of individuals for the most abundant bird species at Campo de Mayo airfield (CMA), listed by season for six consecutive years. Only a posteriori tests are shown for comparisons between tall- and short grasslands.

$\chi_{r}^{2}=$ Friedman's statistic.

$S D=$ standard error

Max = maximum abundance

* statistically-significant differences (a posteriori tests) between bird abundances in the short-vs. tall grassland $(p \leq 0.05)$.

\begin{tabular}{|c|c|c|c|c|c|c|c|c|c|c|}
\hline \multirow[b]{2}{*}{ Species } & \multirow[b]{2}{*}{ Season } & \multirow[b]{2}{*}{$\mathrm{N}$} & \multirow[b]{2}{*}{$\mathrm{x}^{2}$} & \multirow[b]{2}{*}{$\mathrm{p}$} & \multicolumn{3}{|c|}{ Short grassland $(\leq 30 \mathrm{~cm})$} & \multicolumn{3}{|c|}{ Tall grassland $(\succeq 30 \mathrm{~cm})$} \\
\hline & & & & & Mean (SD) & Max. & $\begin{array}{c}\text { Mean } \\
\text { rank }\end{array}$ & Mean (SD) & Max. & $\begin{array}{c}\text { Mean } \\
\text { rank }\end{array}$ \\
\hline Chimango & Spring & 12 & 5,84 & 0,0001 & $29,3(6,21)$ & 70 & 6,33 & $1,6(0,88)$ & 9 & $3,21 *$ \\
\hline \multirow[t]{3}{*}{ Caracara } & Summer & 14 & 7,67 & $<0,0001$ & $48,9(15,95)$ & 165 & 5,89 & $17,6(6,14)$ & 69 & $4,54^{*}$ \\
\hline & Fall & 10 & 2,83 & 0,0181 & $44,6(15,23)$ & 167 & 5,95 & $5(3,42)$ & 35 & $3,2^{*}$ \\
\hline & Winter & 8 & 15,18 & $<0,0001$ & $33,8(11,54)$ & 103 & 6,5 & $1,8(1,28)$ & 10 & $2,06^{*}$ \\
\hline Southem & Spring & 12 & 20,38 & $<0,0001$ & $30,3(6,22)$ & 73 & 6,83 & $1,6(0,73$ & 8 & $3,67^{*}$ \\
\hline \multirow[t]{3}{*}{ Lapwing } & Summer & 14 & 47,73 & $<0,0001$ & $63,6(12,58)$ & 152 & 6,57 & $4,9(1,47)$ & 14 & $4,36 *$ \\
\hline & Fall & 10 & 16,49 & $<0,0001$ & $69,1(9,15)$ & 118 & 7 & $1,9(1,37)$ & 13 & $3,1^{*}$ \\
\hline & Winter & 8 & 21,34 & $<0,0001$ & $46,5(10,82)$ & 111 & 7 & 0 & 0 & $2,94 *$ \\
\hline Pigeons & Spring & 12 & 3,56 & 0,0041 & $3(1,92)$ & 23 & 4,54 & 0 & 0 & $3,17 *$ \\
\hline \multirow[t]{3}{*}{ and Doves } & Summer & 14 & 3,84 & 0,0021 & $9,6(4,3)$ & 61 & 5,25 & $1,5(1,08)$ & 15 & $3,32 *$ \\
\hline & Fall & 10 & 3,4 & 0,0064 & $6(3,46)$ & 35 & 4,5 & 0 & 0 & $3 *$ \\
\hline & Winter & 8 & 5,95 & 0,0001 & $2,4(1,39)$ & 10 & 4,31 & 0 & 0 & 3,13 \\
\hline Monk & Spring & 12 & 1,3 & NS & $2,5(1,69)$ & 15 & - & $0,8(0,83)$ & 10 & - \\
\hline \multirow[t]{3}{*}{ Parakeet } & Summer & 14 & 1 & NS & 0 & 0 & - & 0 & 0 & - \\
\hline & Fall & 10 & 1,39 & NS & $4,5(3,07)$ & 30 & - & 0 & 0 & - \\
\hline & Winter & 8 & 7,87 & $<0,0001$ & $72,4(49,74)$ & 397 & 6,06 & 0 & 0 & $3,38 *$ \\
\hline Common & Spring & 12 & 2,04 & NS & $16,5(10,68)$ & 120 & - & 0 & 0 & - \\
\hline \multirow[t]{3}{*}{ Starling } & Summer & 14 & - & - & 0 & 0 & - & 0 & 0 & - \\
\hline & Fall & 10 & 0,98 & NS & $4,6(2,99)$ & 30 & - & $0,2(0,2)$ & 2 & - \\
\hline & Winter & 8 & 0,73 & NS & $3,8(3,75)$ & 30 & - & 0 & 0 & - \\
\hline
\end{tabular}

\section{Discussion}

Short grassland areas were the most frequently-used habitat by the most abundant species (i.e. Chimango Caracaras and Southern Lapwing), regardless of the season considered, and also by Monk Parakeet in winter. Pigeons and doves used short grasslands more frequently than tall grasslands, and were also the most abundant group in the aerial space. In turn, these species represented a higher risk for aircraft, not only due to their abundances, but also due to their size and degree of aggregation.

Even if it did not present significant differences in its abundance between habitats, the Common Starling was mainly recorded in short grassland areas.

The Southern Lapwing nests on the ground and feeds on invertebrates, while the Common Starling feeds on soil invertebrates and seeds (Feare, 1984; Piersma and Wiersma, 1996). Therefore, short grasslands (<30 cm in height) constitute a very favorable avian habitat for these species, as it has been demonstrated for starlings (Whitehead et al., 1995). The Picazuro Pigeon and the Eared Dove feed on seeds, mostly on the ground (Baptista et al., 1997), while the Monk Parakeet is a generalist that feeds on the grasslands when there is an abundant supply of seeds and grains (Collar, 1997).

The Chimango Caracara is a generalist species that feeds largely on soil insects (Willis, 1994; Biondi et al., 2005), and at CMA in particular this was observed 
coinciding with population outbreaks of the beetle Abderus anomalus (pers.obs.). Chimango Caracara have also been pointed as important predators on Southern Lapwing's nests (White et al., 1994), which happened to be the second-most abundant bird species at the study site, and reproduce in short grassland areas.

Additionally, a visiting group of Chimango Caracaras makes overnight use of shortand tall grasslands at CMA, indistinctly. Control over these has been successful by means of repulsion and banishment techniques (i.e. pyrotechnics; Marateo et al., 2012), given that grassland height has no effect over them.

Tall grasslands of a uniform density can prevent the displacement and social contact among birds, posing an obstacle to anti-predatory vigilance behavior and the search for food. This has been noted for starlings and the Northern Lapwing (Vanellus vanellus) in Canada and Europe (e.g. Solman, 1966; Brough and Bridgman, 1980; Deacon and Rochard, 2000; Devereux et al., 2004; Butler and Gillings, 2004). Maintaining tall grasslands has yielded successful results in UK airports, especially for the control of the Northern Lapwing (Brough and Bridgman, 1980; Deacon and Rochard, 2000), a related and morphologically- and ecologically-similar species to the Southern Lapwing of South America. This strategy has also been effective in the control of starlings and pigeons (Brough and Bridgman, 1980). On the other hand, maintaining grassland height $>30 \mathrm{~cm}$ would also contribute to the numerical reduction of nests of Southern Lapwings and other species, which might in turn represent important food sources for opportunistic rapace birds such as the Chimango Caracara.

Given their wide distributional range, environmental plasticity and ability to expand their geonemia, the bird species considered here, might pose similar risks in other South American airports, as it has been mentioned for the Southern Lapwing in NE and S Brazil, and Uruguay (Bastos, 2000; Galvão Novaes and Del Valle Alvarez, 2010; Guedes et al., 2010; Crocce, 2011). Therefore, it seems reasonable to assume that maintaining grasslands at $>30 \mathrm{~cm}$ heights, might be a successful habitat management technique in the control of avifauna at CMA, and it might also prove effective for other South American airports.

One of the most debated aspects of maintaining grassland height $>20-25 \mathrm{~cm}$, is the potential increase in rodents and insects, which might in turn attract rapaces and other predatory bird species (Barras and Seamans, 2002; Cleary and Dolbeer, 2005). Therefore, a sound management strategy should also incorporate the monitoring of rodent and rapace bird abundances and prevent further population increments. On the other hand, maintaining tall grasslands might prove difficult and costly in arid zones (Cleary and Dolbeer, 2005). For South America specifically, this might not be a big constraint, given that large warm and temperate areas have humid to very humid climate, for which this would be a relatively simple and economic management strategy.

This study represents a starting point for a series of future analyses that should be carried out, considering the management of grassland height and also incorporating its structure, composition and cover extent as potentially important variables. We believe that the incorporation of these variables will shed light into the effectiveness of this habitat management strategy for the control of birds in South American airports.

Acknowledgments. We would like to thank Leopoldo Álvarez, Ignacio Areta, Gabriel Belardinelli, Igor Berkunsky, Melina Brividoro, Lucas Bustos, Nicolás Carro, Marcos Cenizo, Martín Ciancio, Noelia Corrado, Gonzalo Daniele, Leonardo Depentori, Facundo DiSallo, Santiago Escobar, Santiago Fermentini, Analia Francia, Patrick Gado, Valeria Garritano, Claudia Giammaría, Emiliano Guerrero, 
Inés Godoy, Guillermo Grilli, Keila Hidalgo, Melina Hubert, Carlos Jaen, Federico Kacoliris, Mariano Lastra, Mariano Lucía, Lorena Marquez, Lucas Marti, Gabriel Maugeri, Javier Negrete, Paolina Pelichotti, Luciano Pereyra, Romina Pfoh, Sergio Quintero, Laura Ramírez Barrios, Federico Richter, Ignacio Roesler, Roman Ruggera, Gaston Schargorodsky, Gustavo Segura, Luciano Segura, Sergio Seipke, and very specially to Ramiro Almagro, Roberto Jensen and Luis G. Pagano, for their assistance in the field, and authorities and staff of Comando de Aviación del Ejército de Campo de Mayo, for their involvement and contribution to this project. J. Pan translated the manuscript into English. CEAMSE provided funding for this project. The Bird Control Program is financed by CEAMSE (Coordinación Ecológica Area Metropolitana SE), an enterprise advocated to waste management, which operates near CMA airfield. The program is developed both at the Sanitary Landfill and at CMA airfield.

\section{REFERENCES}

[1] ATSB, Australian Transport Safety Bureau (2010): Australian aviation wildlife strike statistics: bird and animal strikes 2002 to 2009 - ATSB Transport Safety Report, Aviation Research and Analysis Report - AR-2009-064, Canberra.

[2] Baptista, L.F., Trail, P.W., Horblit, H.M. (1997): Family Columbidae (Pigeons and Doves) - In: del Hoyo, J., Elliott, A., Sargatal, J. (eds.) Handbook of the Birds of the World, Volume 4: Sandgrouse to Cukoos. Pp. 60-243. Lynx Edicions, Barcelona.

[3] Barras, S.C., Seamans, T.W. (2002): Habitat Management Approaches for Reducing Wildlife Use of Airfields - In: Timm, M., Schmidt, R.H. (eds.) $20^{\circ}$ Vertebrate Pest Conference. Pp. 309-315. University of California, Davis.

[4] Bastos, L.C. (2000): Brazilian avian hazard control program: educational initiatives Proceedings of 25th International Bird Strike Committee meeting. International Bird Strike Committee, Amsterdam.

[5] Biondi, L.M., Bó,, M.S., Favero, M. (2005): Dieta del Chimango (Milvago chimango) durante el período reproductivo en el sudeste de la provincia de Buenos Aires, Argentina - Ornitología Neotropical 16: 31-42.

[6] Brough, T.E., Bridgman, C.J. (1980): An evaluation of long-grass as a bird deterrent on British airfields - Journal of Applied Ecology 17: 243-253.

[7] Burger, J. (1983): Bird control at airports - Environmental Conservation 10: 115-124.

[8] Butler, S.J.. Gillings, S. (2004): Quantifying the effect of habitat structure on prey detectability and accessibility to farmland birds - Ibis 146 (Suppl.2): 123-130.

[9] Carragher, K.A., Clawges, R.M., Bunn, R.L., Pigage, H.K., Pigage, J.C. (2012): Effects of grassland alteration from mowing and fire on bird activity at a Colorado airfield Human-Wildlife Interactions 6: 298-310.

[10] Civil Aviation Authority (2002): Aerodrome Bird Control. CAP 680 - Aerodrome Standards Department, Safety Regulation Group. Gatwick Airport South, West Sussex.

[11] Cleary, E.C., Wright, S.E., Dolbeer, R.A. (1999): Wildlife strikes to civil aircraft in the United States 1990-1998 - U.S. Federal Aviation Administration, Washington D.C.

[12] Cleary, E.C., Dolbeer, R.A. (2005): Wildlife hazard management at airports: a manual for airport personnel 2nd edition - U.S. Department of Agriculture and U.S. Federal Aviation Administration, Sandusky, O.H. and Washington D.C.

[13] Collar, N. J. (1997): Family Psittacidae (Parrots) - In: del Hoyo, J., Elliot, A., Sargatal, J. (eds.) Handbook of the Birds of the World, Volume 4: Sandgrouse to Cukoos. Pp. 280477. Lynx Edicions, Barcelona.

[14] Conover, W.J. (1999): Practical Nonparametric Statistics - John Wiley and Sons, Inc., New York.

[15] Crocce, I. (2011): Comunidad de aves y peligro aviario en el Aeropuerto Internacional de Carrasco - Tesis de Grado, Facultad de Ciencias, Universidad de la República, Uruguay.

[16] Deacon, N., Rochard, B. (2000): Fifty years of airfield grass management in the UK Proceedings of 25th International Bird Strike Committee meeting. International Bird Strike Committee, Amsterdam. 
[17\} Dekker, A., van der Zee, F.F. (1996): Birds and grassland on airports - Bird Strike Committee Europe 23: 291-305.

[18] Devereux, C., Mckeever, C., Benton, T., Whittingham, M. (2004): The effect of sward height and drainage on Common Starlings Sturnus vulgaris and Northern Lapwings Vanellus vanellus foraging in grassland habitats - Ibis 146: 115-122.

[19] Feare, C.J. (1984): The Starling - Oxford, Oxford University Press.

[20] Froneman, A. (2000): Towards the Management of Birds hazards on South African Airports - Proceedings of 25th International Bird Strike Committee meeting. International Bird Strike Committee, Amsterdam.

[21] Galvão Novaes, W., Del Valle Alvarez, M.R. (2010): O perigo aviário em aeroportos do nordeste do Brasil: análise das colisões entre aves e aviões entre os anos de 1985 e 2009 Revista Conexão SIPAER 1: 47-68.

[22] Guedes, F.L., Brand, D.L., de Paiva Linhares, B., Vieira de Paiva, L. (2010): Avifauna relacionada ao risco de colisões aéreas no Aeroporto Internacional Presidente Juscelino Kubitschek, Brasília D.F., Brasil. - Revista Conexão SIPAER 2: 230-243.

[23] Hygnstrom, S.E., Timm, R.M., Larson, G.E. (eds.) (1994): Prevention and control of wildlife damage, 2 vols. University of Nebraska-Lincoln.

[24] ICAO, International Civil Aviation Organization (2001): Airport services manual. Seminar on bird hazards, environmental protection and land use at airports for the NAM/CAR/SAM Regions, Miami.

[25] ICAO, International Civil Aviation Organization (2009): ICAO safety management manual. Montreal, Canadá.

[26] Marateo, G., Grilli, P., Ferretti V., Bouzas, N. (2011): Diagnóstico de riesgo aviario en un aeródromo de un Área Megadiversa de Perú - Revista Conexão SIPAER 2: 203-227.

[27] Marateo, G, Grilli, P.G., Soave, G.E., Ferretti, V., Bouzas, N.M., Almagro, R.: Aves y aeropuertos: control no letal de Chimangos (Milvago chimango) en un aeródromo militar de Argentina - Gestión y Ambiente 15: 89-98.

[28] Mead, H., Carter, A.W. (1973): The management of long grass as a bird repellent on airfields - Journal of British Grassland Society 28: 219-221.

[29] Neubauer, J.C. (1990): Why birds kill: Cross-sectional analysis of U.S. Air Force bird strike data - Aviation, Space and Environmental Management 61: 343-348.

[30] Piersma, T., Wiersma, P. (1996): Family Charadriidae (Plovers) - In: del Hoyo, J., Elliot, A., Sargatal, J. (eds.) Handbook of the Birds of the World, Volume 3: Hoatzin to Auks. Pp. 384-443. Lynx Edicions, Barcelona.

[31] Seamans, T.W., Dolbeer, R.A., Carrara, M.S., Chipman, R.B. (1999): Does tall grass reduce bird numbers on airports?: Results of pen test with Canada geese and field trials at two airports, 1998 - Proceedings Joint Meeting of Bird Strike Committee Canada and Bird Strike Committee USA. Vancouver, British Columbia.

[32] Seamans, T.W., Barras, S.C., Bernhardt, G.E., Blackwell, B.F., Cepek, J.D. (2007): Comparison of 2 vegetation-height management practices for wildlife control at airports Human-Wildlife Conflicts 1: 97-105.

[33] Smith, M. (1986): From a strike to kill - New Scientist 110: 44-47.

[34] Sodhi, N.S. (2002): Competition in the air: birds versus aircraft - Auk 119: 587-595.

[35] Solman, V.E.F. (1966): Ecological control of bird hazard to aircraft - Proceedings of the Bird Control Seminar 3: 38-56.

[36] Transport Canada (2002): Wildlife control procedures manual - Transport Canada, Otawa.

[37] Washburn, B.E., Seamans, T.W. (2004): Management of vegetation to reduce wildlife hazards at airports - FAA Worldwild Airport Technology Transfer Conference. Atlantic City, New Jersey. 
[38] White, C.M., Olsen, P.D., Kiff, L.F. (1994): Family Falconidae - In: del Hoyo, J., Elliott, A., Sargatal, J. (eds.) Handbook of the Birds of the World, Vol. 2: New World Vultures to Guineafowl. Pp. 216-275. Lynx Edicions, Barcelona.

[39] Whitehead, S.C., Wright, J., Cotton, P.A. (1995): Winter field use by the European Starling Sturnus vulgaris - habitat preferences and the availability of prey - Journal of Avian Biology 26: 193-202.

[40] Willis, I. (1994): Family Falconidae - In: del Hoyo, J., Elliott, A., Sargatal, J. (eds.) Handbook of the Birds of the World, Vol 2: New World Vultures to Guineafowls, Pp. 248-251. Lynx Editions, Barcelona. 